\begin{tabular}{ll}
\hline & Jurnal Sains Materi Indonesia \\
Homepage: http://jusami.batan.go.id & $\begin{array}{l}\text { Akreditation No : 21/E/KPT/2018 } \\
\text { Date 9 July 2018 } \\
\text { ISSN 1411-1098 } \\
\text { E-ISSN 2614-087X }\end{array}$ \\
\hline
\end{tabular}

\title{
THE POTENTIAL OF INDONESIAN GRAPHITE AS RDE FUEL MATRIX
}

\author{
Deni Mustika'), Sudirman'), Adel Fisli' ${ }^{2)}$, Torowati'), I Made Joni' ${ }^{3)}$, Th. Rina M.2) \\ ${ }^{1)}$ Pusat Teknologi Bahan Bakar Nuklir - BATAN, Kawasan Puspiptek Serpong, 15314 \\ ${ }^{2)}$ Pusat Sains dan Teknologi Bahan Maju - BATAN, Kawasan Puspiptek Serpong, 15314 \\ ${ }^{3)}$ Pusat Riset Institusi Nanoteknologi dan Graphene (PrintG), DRPMI UNPAD, Jln. Raya Bandung-Sumedang \\ Km. 21 Jatinangor, Kab. Sumedang 45363 \\ E-mail: dmustika@batan.go.id
}

Received: 3 September 2018

Revised: 6 December 2018

Accepted: 13 December 2018

\begin{abstract}
THE POTENTIAL OF INDONESIAN GRAPHITE AS RDE FUEL MATRIX. The development plan of Experimental Power Reactor (RDE) in Indonesia is non-commercial and leads to the technology type of Pebble Bed Reactor (PBR) - High Temperature Gas Cooled Reactor (HTGR). The fuel used for PBR reactors is kernel dispersed in spherical fuel elements. The matrix used in PBR nuclear fuel is graphite which functions as a neutron moderator, fuel protective material and heat conductor. Domestication of the domestic fuel matrix needs to be conducted to improve national independence. Therefore, it is necessary to do research on the potential of local graphite to be used as RDE fuel matrix. This study focused on the identification and characterization of local and commercial graphite. The results are compared with the literature, how far it is fulfilling nuclear grade graphite for PBR fuel matrix. Characterization of graphite includes phase analysis with XRD, microstructure with SEM, surface area/porosity, impurities determination with AAS, ICP-OES and NAA, equivalent boron content, carbon content, density, particle size distribution and ash content. The characterization results show that the carbon content obtained was $87.0 \pm 4.2 \%$ for local graphite and $100 \%$ for commercial graphite. Meanwhile, for the purposes of nuclear graphite it requires a carbon content of $>99 \%$. The impurity content in local and commercial graphite still does not meet the RDE fuel matrix standard. The results of XRD analysis show that the local graphite phase is the same as the commercial graphite phase, namely the $2 \mathrm{H}$ graphite hexagonal crystal system with the lattice group of $\mathrm{P} 63 / \mathrm{mmc}$. Particle size distribution and surface area of local graphite are higher compared to nuclear graphite literature. The ash content of commercial graphite was $0.236 \pm 0.029$ and local graphite was $9.587 \pm 0.010 \%$. The results of this study indicate that the local graphite from the flotation still requires a further refinement process to obtain local graphite that can be used as a fuel matrix for RDE.
\end{abstract}

Keywords: Natural graphite, matrix, fuel, PBR, RDE, characterization

\section{ABSTRAK}

POTENSI GRAFIT INDONESIA SEBAGAI MATRIKS BAHAN BAKAR RDE. Rencana pembangunan Reaktor Daya Eksperimental (RDE) di Indonesia bersifat non-komersial dan mengarah ke teknologi jenis Pebble Bed Reactor (PBR) - High Temperature Gas Cooled Reactor (HTGR). Bahan bakar yang digunakan untuk reaktor PBR adalah kernel yang terdispersi dalam elemen bakar sferis (bola). Matriks yang digunakan pada bahan bakar nuklir PBR adalah grafit yang berfungsi sebagai moderator neutron, material pelindung bahan bakar dan konduktor panas. Domestifikasi matriks bahan bakar dalam negeri pelu dilakukan untuk meningkatkan kemandirian bangsa. Oleh karena itu, perlu dilakukan penelitian tentang potensi grafit lokal untuk digunakan sebagai matriks bahan bakar RDE. Penelitian ini difokuskan pada identifikasi dan karakterisasi grafit lokal dan komersial. Hasilnya dibandingkan terhadap literatur, seberapa jauh memenuhi grafit berderajat nuklir untuk matriks bahan bakar PBR. Karakterisasi grafit meliputi analisis fasa dengan XRD, struktur mikro dengan SEM, luas permukaan/porositas, penentuan impuritas dengan AAS, ICP-OES and NAA, boron ekuivalen, kandungan karbon, densitas, distribusi ukuran partikel dan kadar abu. Hasil karakterisasi menunjukkan bahwa kandungan karbon diperoleh 87,0 $\pm 4,2 \%$ untuk grafit lokal dan 100\% untuk grafit komersial. Sementara, untuk keperluan grafit nuklir membutuhkan kandungan karbon $>99 \%$. Kandungan impuritas dalam grafit lokal dan komersial masih belum memenuhi standar matriks bahan bakar RDE. Hasil analisis XRD menunjukkan bahwa fasa grafit lokal sama dengan fasa grafit komersial yaitu grafit $2 \mathrm{H}$ sistem kristal heksagonal dengan grup kisinya adalah P 63 /mmc. Distribusi ukuran partikel dan luas permukaan grafit lokal lebih tinggi dibanding dengan grafit nuklir literatur. Kadar abu grafit komersial diperoleh $0,236 \pm 0,029$ dan grafit lokal sebesar 9,587 $\pm 0,010 \%$. Hasil dari penelitian ini, menunjukkan bahwa grafit lokal hasil flotasi masih memerlukan proses pemurnian lebih lanjut supaya diperoleh grafit lokal untuk dapat digunakan sebagai matriks bahan bakar untuk RDE.

Kata kunci: Grafit alam, Matriks, Bahan bakar, PBR, RDE, karakterisasi 


\section{INTRODUCTION}

Constructon of non-commercial Experimental Power Reactors (RDE) leads to the technology type of Pebble Bed Reactor (PBR) - High Temperature Gas Cooled Reactor (HTGR). This type of reactor was chosen as it has very high safety features due to its passive safety features in the form of the ability to manage cooling performance without the need for external assistance and flexible applications, besides being able to generate electricity, it also produces high temperature steam which can be used for coal liquefaction, water desalination and water production [1]. The fuel used for PBR reactors is a kernel dispersed in spherical fuel elements. Kernel fuel contains $\mathrm{UO}_{2}$ called TRISO (Tristructural-isotropic) particles coated with buffers, Inner Pyrocarbon (Ipyc), SiC and Outer Pyrocarbon (Opyc). These kernel fuels are in the thousands, dispersed in the graphite matrix of fuel elements $[2,3,4]$.

PBR fuel matrix is an A3-3 graphite matrix with a composition of natural graphite of $64 \%$, synthetic graphite $16 \%$ and phenolic resin $20 \%$. With the mixture of natural graphite and synthetic graphite, the material obtained can be compressed; the material is quite strong and purer. This characteristic is obtained from the nature of synthetic graphite which has high purity and is less anisotropic and natural graphite which can be reduced in size to very fine $[2,5,6]$.

Efforts for the RDE program can continue by leading to Nuclear Power Plants (NPP) and to create energy sovereignity, then Indonesia needs to conduct Development on RDE Fuel Fabrication Technology. Mastery of RDE fuel fabrication technology for power reactor pilot projects with a capacity of around $10 \mathrm{MW}$ with the HTR-10 Pebble Bed Reactor (PBR) type, including the mastery of kernel production technology, production of TRISO coated particles, and fuel spheres to produce fuel that meets required specifications. In addition to the need for nuclear-grade fissile material that can split in the reactor, moderator materials and the structure of the fuel protective material in accordance with the requirements are also necessary. The graphite matrix functions as a neutron moderator, fuel protective material structure, and heat transfer media [7].

Graphite is one of the allotropes of crystalline carbon which has good nuclear physical characteristics such as high efficiency of reflection and moderation, relatively low atomic mass, low neutron uptake latitude, high mechanical strength, high temperature resistance, easy fabrication and light mass [5]. Natural graphite as a constituent of $\mathrm{A} 3-3$ graphite matrix used in PBR type fuels must meet the criteria of physical and chemical properties including purity, impurity content, boron equivalent content, surface area, particle size distribution, ash content and density. Graphite is a natural element with a carbon composition $(\mathrm{C})$ with a hexagonal crystal system and has a density of $2.23 \mathrm{~g} / \mathrm{cm}^{3}$. Yeo et. al, Tang et. al and Zhao et. al use natural graphite as HTGR fuel matrix with high purity (> 99\%), lithium content $<0.005 \mu \mathrm{g} / \mathrm{g}$, boron equivalent content $<1 \mu \mathrm{g} / \mathrm{g}$ and ash content $\sim 100 \mu \mathrm{g} / \mathrm{g}$ with graphite surface area used of $4.8-5.5 \mathrm{~m}^{2} / \mathrm{g}$, with microstructure form which is more flattened and sharper compared to synthetic graphite. Graphite particle size distribution used by Yeo et. Al and Tang et. al is $90 \%$ with a range of 32 $63 \mu \mathrm{m}$, Zhao et. al used graphite with a size of $<80 \mu \mathrm{m}$ with $71.20 \%$ of $<25 \mu \mathrm{m}$. The particle size distribution based on TecDoc 1674 is $50 \%$ particle size of $<32 \mu \mathrm{m}$ $[2,3,4]$.

In China, around 60 tons of graphite has been used for fuel of High Temperature Gas - Coooed Reactor (HTR) - 10 and more than 1000 tons will be used for High Temperature Gas - Cooled Reactor PebbleBed Module (HTR-PM) [8]. It takes around 27000 PBR fuel for initial operation of RDE and 105 fuel per day to achieve steady state [1]. The need for graphite matrix per fuel is $0.2 \mathrm{~kg}$ so it takes about 156 tons of graphite for 20 years to operate $1 \mathrm{RDE}$ with a capacity of 10 MW.

Graphite research for the nuclear sector began in 2007 in the form of synthetic graphite derived from calcine coke and Tar Pitch [9]. Natural graphite from Sulawesi has been refined by flotation method and obtained a carbon content of $61 \%$ [10]. Natural graphite from Kalimantan has been purified by flotation and acid process (HF) methods and obtained a carbon content of more than $90 \%[11,12]$. Flotation method is a method of separation and concentration based on differences in inter-phase chemical properties. Graphite naturally floats in water because it is hydrophobic; some suitable reagents are added to increase its recovery [10].

From the research, the results of the study have not been obtained on the potential of Indonesian natural graphite to be used as RDE matrix with higher purity and characteristics according to specifications. To domesticate the domestic fuel matrix and improve national independence, it is necessary to study local graphite as an RDE fuel matrix. This study aims to figure out the potential of local graphite as RDE fuel matrix and commercial (synthetic) graphite as a comparison.

Indonesia has quite a lot of graphite mineral deposits in Sulawesi and Kalimantan regions. In Sulawesi, graphite rocks are found in Tamboli, Samaturu Subdistrict, Kolaka Regency, Southeast Sulawesi with $3 \%$ graphite content and the main compound was calcite $\left(\mathrm{CaCO}_{3}\right)$ and explored by PT Mekongga Sejahtera [10] with an exploration permit covering 98 ha. In $\mathrm{Su}-$ lawesi, graphite is also found in Latambaga Subdistrict, Kolaka Regency, Southeast Sulawesi in the form of slate with the result of major chemical graphite minerals is $\mathrm{SiO}_{2}$ with a percentage of $29.08 \%-70.76 \%$ and carbon content of $2.36 \%-4.51 \%$ [13].

In Kalimantan, graphite is found in Balai Sebut Subdistrict, Sanggau Regency, West Kalimantan identified as having graphite mineral content along with other minerals with the main compound of $\mathrm{SiO}_{2}$ $24.27-90.12 \%$, with carbon content of $1.25 \%-65.56 \%$ 
and mineral in the form of slate mud stone [13]. In Sanggau Regency, PT. Trans Sulawesi Sejahtera holds a graphite mining business permit with an area of 10,000 Ha and PT. Trans Sulawesi Tenggara (TST) with an area of $80.5 \mathrm{Ha}$.

In Sumatra, graphite is found in Muara Saiti Pangkalan and Tanjung Balit, Lima Puluh Kota Regency (an insertion in schist rocks), in Ombilin in the Singkarak Lake area and in Siberlabu Payakumbuh [14].

\section{EXPERIMENTAL METHOD Materials and Equipment}

The materials used were natural graphite from Kalimantan, $\mathrm{HNO}_{3}$ pro analysis (Merck), $\mathrm{H}_{2} \mathrm{SO}_{4}$ pro analysis (Merck), Element Standards AAS and ICP OES (Merck), HP acetylene gas, HP nitrous oxide gas, UHP argon gas, and UHP helium gas.

The equipment used was XRD (Panalytical) for crystal-lography, particle size analyzer (PSA) micro with the brand of Cilas 1190 Liquid with the Fraunhofer method for particle size distribution, Scanning Electron Microscopy with Energy Dispersive Spectroscopy (SEM-EDS) Jeol 6510LA and Carbon and Sulfur Analyzer, (CS 744 LECO) for carbon content. He - Ultrapyc 1200-e autopycnometer, Quantachrome for determination of density, Bicasa-brand Furnace for determination of ash content. Neutron Activation Analysis (NAA), flame - Atomic absorption Spectrometer (FAAS) and Agilent-brand ICP - OES for determination of impurity and boron equivalent and high performance microwave digester systems area used for preparation. Surface area and pore size analyzer Quadrasorb SI, Quantachrome is for determining the surface area of Brunauer Emmet Teller (BET) and porosity. Scanning Electron Microscopy (SEM) Jeol 6510LA is for microstructure analysis.

\section{Procedure}

Chemical and physical characterization was carried out to figure out the potential and source of graphite in Indonesia as RDE fuel matrix. Natural graphite from Kalimantan was initially refined using the flotation method [11], then identified and characterized, and the results were compared with commercial (synthetic) graphite from Merck. Characterization includes crystallography, particle size distribution, carbon content, density, ash content, impurity and equivalent boron content, BET surface area, porosity and microstructure.

Crystallographic characterization was performed using XRD (Panalytical), particle size distribution used micro particle size analyzer (PSA) Cilas 1190 Liquid with the Fraunhofer method, the carbon content was determined by SEM/EDS Jeol 6510LA using ZAF method standardless quantita-tives analysis and Carbon and Sulfur Analyzer, (CS 744 LECO). Determination of density used He - autopycnometer Ultrapyc 1200-e, Quantachrome. Ash content was determined by the loss on ignition method at a temperature of $\pm 950^{\circ} \mathrm{C}$. Impurities and boron equivalent used Neutron Activation Analy-sis (AAN), Flame - Atomic Absorption Spectrometer (F-AAS) and Agilent-brand ICP - OES. Measurements with AAN, samples were analyzed without treatment while for AAS and ICP-OES, graphite samples were dissolved first with a mixture of acids $\left(\mathrm{HNO}_{3}\right.$ and $\mathrm{H}_{2} \mathrm{SO}_{4}$ ) in a microwave digester. BET surface area and porosity were determined using Surface area and pore size analyzer Quadrasorb SI, Quantachrome. Graphite SEM images were taken using Scanning Electron Microscopy (SEM) Jeol 6510LA.

\section{RESULTS AND DISCUSSION \\ Characterization of commercial graphite and Indo- nesian (local) natural graphite}

The results of the analysis of crystallographic diffraction patterns of local and commercial graphites with 2 Theta 20 - 80 are presented in Figure 1. The results of diffractogram comparison of commercial graphite shown in Figure 1 were performed using Highscore Plus application from Panalytical using COD database. The results show that there is a phase match for commercial graphite with card numbers 96101-1061. The compatibility of the graphite phase obtained on card numbers 96-101-1061 is $2 \mathrm{H}$ graphite with a hexagonal crystal system and the lattice group is P $63 \mathrm{~m}$ c with a peak of $2 \Theta 26.228^{\circ}, 42.214^{\circ}, 44.365^{\circ}$, $50.381^{\circ}, 53.974^{\circ}, 59.404^{\circ}, 70.804^{\circ}, 77.177^{\circ}$. Based on the semi quantitative calculation results, the percentage of $2 \mathrm{H}$ graphite in commercial graphite (red diffractogram) is 100 percent, while for natural graphite (blue diffractogram), there is a phase similar to commercial graphite, but there is a peak residual at 2 ○ $28.442^{\circ}$, $36.10^{\circ}, 40^{\circ}, 43.94^{\circ}$ and $73.889^{\circ}$ which indicate that natural graphite contains another large phase. The results of phase compatibility of the COD database against the residual peaks obtained include copper with cards number 96-901-3016, with a cubic crystal system and lattice group of Fm-3m with a peak at $2 \Theta 43.94^{\circ} ; 50.21^{\circ}$ and $74.15^{\circ}$. Rietveld method is used to determine the c/a ratio and is obtained for commercial graphite and natural graphite of 2.7411 and 2.7294, respectively. The c/a ratio obtained is lower com-pared to $2 \mathrm{H}$ graphite with cards number 96-101-1061, as 2.7489.

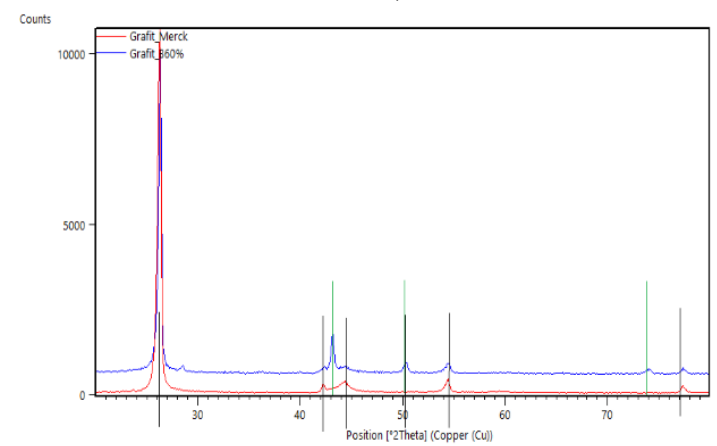

Figure 1. X-ray diffraction pattern of commercial and local graphite. Black line is $2 \mathrm{H}$ graphite, green line is $\mathrm{Cu}$ metal. 


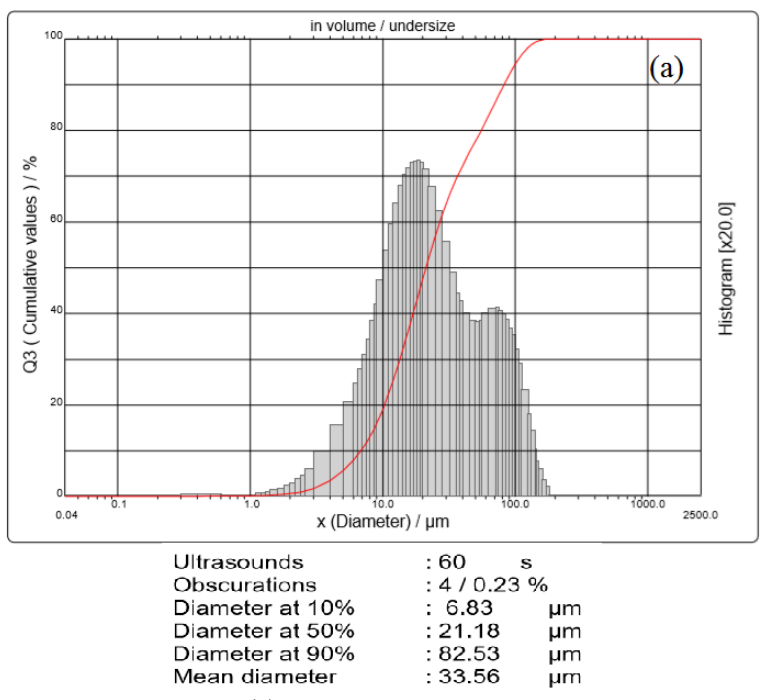

(a)

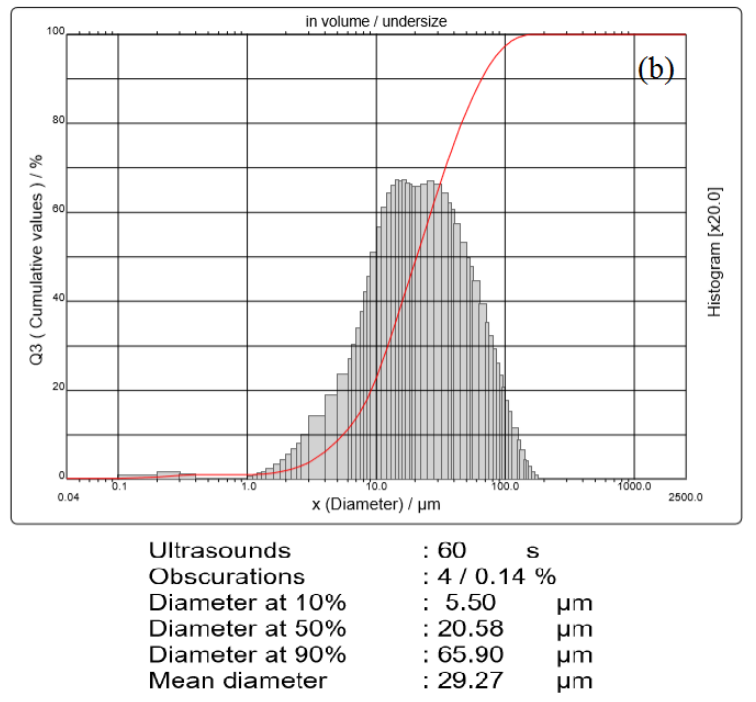

(b)

Figure 2. Particle size distribution of (a) commercial graphite and (b) local graphite

The results of the density measurement of commercial graphite is obtained at $2.311 \mathrm{~g} / \mathrm{cm}^{3}$ and local graphite at $2.334 \mathrm{~g} / \mathrm{cm}^{3}$. Graphite density obtained both commercially and locally is higher than the graphite density in the literature (graphite density value in literature is $2.09-2.266 \mathrm{~g} / \mathrm{cm}^{3}$ ) $[13,14]$. Zhao et al explained that the density of graphite as a spherical nuclear fuel matrix is greater than $1.70 \mathrm{~g} / \mathrm{cm}^{3}$ [3].

The results of particle size distribution were deter-mined using particle size analyzer Cilas as shown in Figure 2. Figure 2(a) shows that commercial graphite has an average particle size of $33.56 \mu \mathrm{m}$ with a distribution of $10 \%$ to $90 \%$ is $6.83-82.53 \mu \mathrm{m}$, while local graphite as shown in Figure 2(b) has a average particle size of $29.27 \mu \mathrm{m}$ with a distri-bution of $10 \%$ to $90 \%$ is $5.50-65.90 \mu \mathrm{m}$. These results indicate that commercial graphite has a larger particle size distribution than local graphite. Meanwhile for the requirements for nuclear fuel needs, the dominant size of graphite diameter is $<25 \mu \mathrm{m}$ [3] and $32-63 \mu \mathrm{m}$ [4]. Based on this particle size distribution, both local graphite and commercial graphite have a greater range of requirements as nuclear graphite. The large average diameter and particle size distribution have an effect on the fabrication process and the graphite matrix density produced after compacting. Larger powder diameters cause many cavities so that smaller powder is needed to fill the cavity (as a filler). If the cavity is not filled, the density of the graphite ball will be lower and the graphite matrix will be easily cracked (low mechanical strength) [3].

The spectrum of measurement of carbon content with EDS is shown in Figure 3. The measurement results obtain the percentage of carbon mass of commercial graphite (Figure 3(a) as $100 \pm 0.16 \%$ and local graphite (Figure 3(b) $89.68 \pm 0.06 \%$ with the fitting coefficient is 0.3999 and 0.1994 , re-spectively. These results are almost the same as the deter-mination of carbon using a carbon analyzer. The amount of carbon content in commercial graphite is obtained as $100 \pm$
$1.3 \%$ and local graphite as $87.0 \pm 4.2 \%$. The carbon content of commercial graphite has met the requirements as nuclear graphite (nuclear graphite carbon content $>99 \%$ ) [3], however, local graphite has not met them, so it still requires further processing to refine the carbon content to reach $>99 \%$.

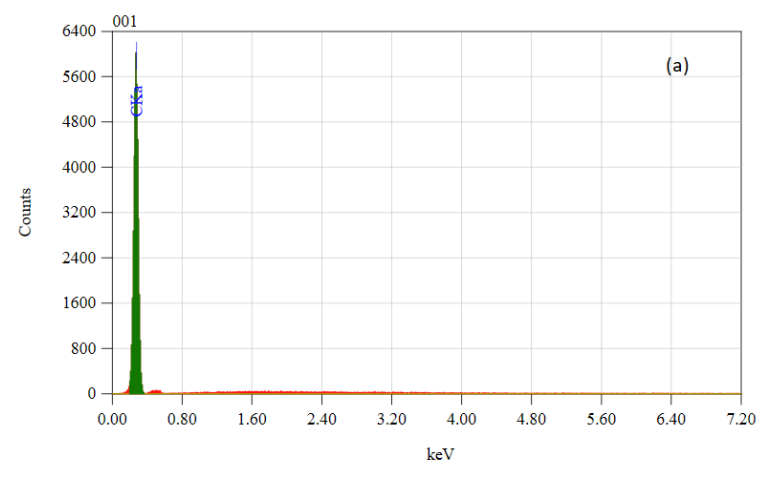

ZAF Method Standardless Quantitative Analysis Fitting Coefficient : 0.3999

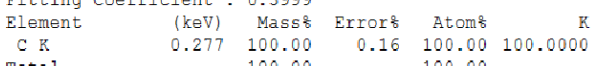
Total $100.00 \quad 100.00$

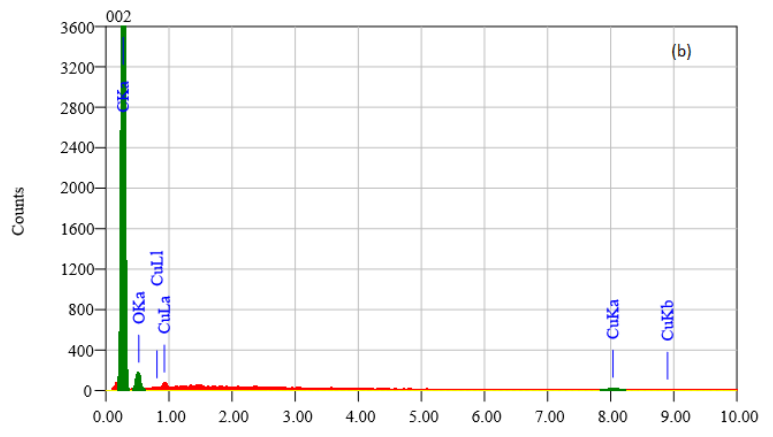

$\mathrm{keV}$

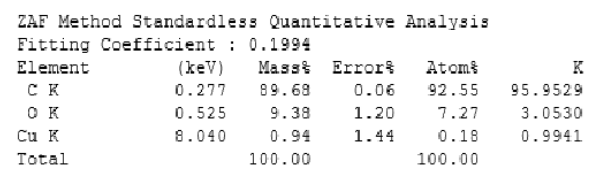

Figure 3. EDS Spectrum of (a) Commercial graphite and (b) Local graphite 
Determination of graphite impurity is conducted by several methods; so that the results of the overall elemental impurity analysis in graphite can be known as each measurement method has different analytical skills. There are two analytical methods for determining impurity in graphite, namely; non-destructive test with neutron activation analysis (NAA) and destructive test with AAS and ICP-OES. Table 1 shows the results of impurity determination in local and commercial graphites with AAS, AAN and ICP-OES analysis methods. Table 1 shows that there are 31 elements determined by the three methods. In general, impurity concentrations in local graphite are higher compared to commercial graphite. In local graphite, there are 18 elements that can be determined, namely; $\mathrm{Al}, \mathrm{Co}, \mathrm{Cr}, \mathrm{Cu}$, $\mathrm{Dy}, \mathrm{Fe}, \mathrm{K}, \mathrm{La}, \mathrm{Mg}, \mathrm{Mn}, \mathrm{Na}, \mathrm{Ni}, \mathrm{Pb}, \mathrm{Sb}, \mathrm{Sc}, \mathrm{V}, \mathrm{W}$ and $\mathrm{Zn}$, whereas other elements such as $\mathrm{Ag}, \mathrm{B}, \mathrm{Ba}, \mathrm{Ca}, \mathrm{Ce}$, $\mathrm{Cd}, \mathrm{Eu}, \mathrm{Hf}, \mathrm{Li}, \mathrm{Si}, \mathrm{Sm}$, Th and Ti are not detected/below the limit of detector. The highest concentration of elements obtained in $\mathrm{Cu}$ reached $45660 \mu \mathrm{g} / \mathrm{g}(4.5 \%)$, followed by Dy $24540 \mu \mathrm{g} / \mathrm{g}(2.45 \%)$, Sb $2324 \mu \mathrm{g} / \mathrm{g}$ (0.232\%), Fe $1379 \mu \mathrm{g} / \mathrm{g}(0.1379 \%)$ and $\mathrm{Al} 1071 \mu \mathrm{g} / \mathrm{g}$ $(0.1071 \%)$. Elements of $\mathrm{Mg}, \mathrm{Pb}$, and $\mathrm{Zn}$ are in the concentration range of 190 to $451 \mu \mathrm{g} / \mathrm{g}$ and concentration of others is below $100 \mu \mathrm{g} / \mathrm{g}$. Whereas for commercial graphite, it is known that 24 elements, with the highest element content is obtained for Dy element at 6805,833 $\mu \mathrm{g} / \mathrm{g}$ followed by $\mathrm{Fe} 433 \mu \mathrm{g} / \mathrm{g}$ and $\mathrm{Cr} 144 \mu \mathrm{g} / \mathrm{g}$, and others below $100 \mu \mathrm{g} / \mathrm{g}$.

The presence of impurity in graphite results in a catalytic effect on carbon elements. The catalytic effect of this metal can accelerate the oxidation of graphite struc-tures [15], and cause fuel failure due to the chemical reaction between carbon and impurity [16].

The magnitude of the effect of the oxidation speed de-pends on the type and concentration of impurity. The pres-ence of impurity at a certain level can increase the speed of graphite oxidation to 2-3 times. There are several elements that have a catalytic effect on graphite, namely; Ti, V, Cr, Fe, Mo, W, Re, Ru, Rh, $\mathrm{Ir}, \mathrm{Cu}, \mathrm{Zn}, \mathrm{Pd}, \mathrm{Ag}, \mathrm{Pt}$ and Eu. At nuclear graphite with high purity, total impurity concentration does not exceed $300 \mathrm{ug} / \mathrm{gr}$. As graphite with low purity, the impurity concentration is allowed to be a maximum of 1,000 $\mu \mathrm{g} / \mathrm{g}$ [17]. High impurity content can also reduce resistance to corrosion, reduce thermal conductivity and reduce irradiation performance of fuel [3].

Table 1. Impurity data of commercial and local graphites

\begin{tabular}{|c|c|c|c|}
\hline \multirow[t]{2}{*}{ Element } & \multicolumn{2}{|c|}{ Content $(\mu \mathrm{g} / \mathrm{g})$} & \multirow[t]{2}{*}{ Method } \\
\hline & $\begin{array}{c}\text { Commercial } \\
\text { graphite }\end{array}$ & Local graphite & \\
\hline Ag & $49.740 \pm 0.0990$ & $<\operatorname{LoD} 0.2823$ & AAS \\
\hline Al & $39.59 \pm 5.25$ & $1071.35 \pm 40.60$ & AAN \\
\hline B & $<\operatorname{LoD} 12.501$ & $<$ LoD 12.5012 & AAS \\
\hline $\mathbf{B a}$ & $10.46 \pm 1.80$ & Not detected & AAN \\
\hline $\mathbf{C a}$ & $<\operatorname{LoD} 0.3819$ & $<\operatorname{LoD} 0.3819$ & AAS \\
\hline $\mathrm{Ce}$ & $1.44 \pm 0.04$ & Not detected & AAN \\
\hline Cd & $<$ LoD 0.0015 & $<\operatorname{LoD} 0.0015$ & AAS \\
\hline
\end{tabular}

\begin{tabular}{llll}
$\mathbf{C o}$ & $0.40 \pm 0.01$ & $7.98 \pm 0.83$ & AAN \\
$\mathbf{C r}$ & $144.027 \pm 0.1798$ & $74.800 \pm 0.140$ & AAS \\
$\mathbf{C u}$ & $65.322 \pm 0.160$ & $45660 \pm 72.00$ & AAS \\
$\mathbf{D y}$ & 6805.833 & 24540 & ICP \\
$\mathbf{E u}$ & $0.02 \pm 0.001$ & Not detected & AAN \\
$\mathbf{F e}$ & $433.080 \pm 0.999$ & $1379.20 \pm 80.00$ & AAS \\
$\mathbf{H f}$ & $0.03 \pm 0.001$ & Not detected & AAN \\
$\mathbf{K}$ & $8.640 \pm 0.02$ & $78.080 \pm 0.620$ & AAS \\
$\mathbf{L a}$ & $0.73 \pm 0.04$ & $1.05 \pm 0.09$ & AAN \\
$\mathbf{L i}$ & $<$ LoD 1.8600 & $<$ LoD 1.8600 & AAS \\
$\mathbf{M g}$ & $6.992 \pm 0.998$ & $253.400 \pm 4.60$ & AAS \\
$\mathbf{M n}$ & $5.31 \pm 0.31$ & $10.33 \pm 0.73$ & AAN \\
$\mathbf{N a}$ & $84.90 \pm 1.56$ & $85.10 \pm 1.60$ & AAN \\
$\mathbf{N i}$ & $60.927 \pm 0.1797$ & $70.600 \pm 0.24$ & AAS \\
$\mathbf{P b}$ & $<$ LoD 60.500 & $190 \pm 0.18$ & AAS \\
$\mathbf{S b}$ & $0.40 \pm 0.01$ & $2324.59 \pm 273.10$ & AAN \\
$\mathbf{S c}$ & $0.25 \pm 0.01$ & $0.44 \pm 0.03$ & AAN \\
$\mathbf{S i}$ & $<$ LoD 1,2000 & $<$ LoD 1,2000 & AAS \\
$\mathbf{S m}$ & $0.03 \pm 0.001$ & Not Detected & AAN \\
$\mathbf{T h}$ & $0.16 \pm 0.01$ & Not Tedected & AAN \\
$\mathbf{T i}$ & $<$ LoD 1.200 & $<$ LoD 1.200 & AAS \\
$\mathbf{V}$ & $3.61 \pm 0.39$ & $34.04 \pm 1.33$ & AAN \\
$\mathbf{W}$ & $0.38 \pm 0.03$ & $15.00 \pm 0.86$ & AAN \\
$\mathbf{Z n}$ & $3.77 \pm 0.24$ & $451.27 \pm 31.73$ & AAN \\
\hline & & &
\end{tabular}

Other types of impurity that need to be avoided in the graphite matrix are the elements that contribute to absorb-ing neutrons. The neutron absorption rate of an element of impurity can be expressed by Equivalent Boron Content-EBC as shown in equation 1 [18].

Total EBC $=\sum\left(\frac{E B C \text { Factors }}{\text { impurity content }\left({ }^{\mu g} / g\right)}\right) \ldots \ldots \ldots$

In determining $\mathrm{EBC}$, it is known that elements $\mathrm{B}, \mathrm{Dy}, \mathrm{Eu}, \mathrm{Gd}, \mathrm{Sm}, \mathrm{Li}$ and $\mathrm{Cd}$ are impurities with a large EBC factor, each of which is 1.000; 0.0818; $0.4250 ; 4.3991 ; 0.5336 ; 0.4139$ and 0.3172 . Addition to the 6 elements above, the element EBC factor is 0.0001 to 0.0263 with a small contribution to neutron absorption. In Table 1, the content of elements B, Eu, $\mathrm{Gd}, \mathrm{Sm}, \mathrm{Li}$ and $\mathrm{Cd}$ is not detected, while the Dy concentration in commercial graphite is relatively high $(6805.85 \mu \mathrm{g} / \mathrm{g})$ and local graphite as $24540 \mu \mathrm{g} / \mathrm{g}$. This equivalent boron content is higher than nuclear graphite at $<1 \mu \mathrm{g} / \mathrm{g}$ [3] and $<3.0 \mu \mathrm{g} / \mathrm{g}$ [2].

Images of commercial graphite and local graphite are presented in Figure 4. Commercial graphite morphology looks flatter with sharper sides compared to local graphite. The morphological form is similar to graphite powder produced by Sunghwan Yeo, et.al. [4].

The surface area of commercial and local graphite was obtained respectively at 10.54 and 11.41 $\mathrm{m}^{2} / \mathrm{g}$. In some literature it is stated that the graphite surface area with nuclear grade varies in the range of 1.15 $\mathrm{m}^{2} / \mathrm{g}$ to $5.55 \mathrm{~m}^{2} / \mathrm{g}[3,4]$, however, the surface area obtained in both local graphite and commercial graphite is still higher compared to $\mathrm{H}$ grafite from Zhao, et. al and S. Yeo, et.al. This higher surface area might be re- 
lated to graphite particle size. Pore volume of local graphite is higher than commercial graphite. This is related to the impurity content in the graphite structure. With the presence of particle impurity which is sufficiently high in the graphite structure, it forms cavities between the graphite structures so that the local graphite pore volume is higher.
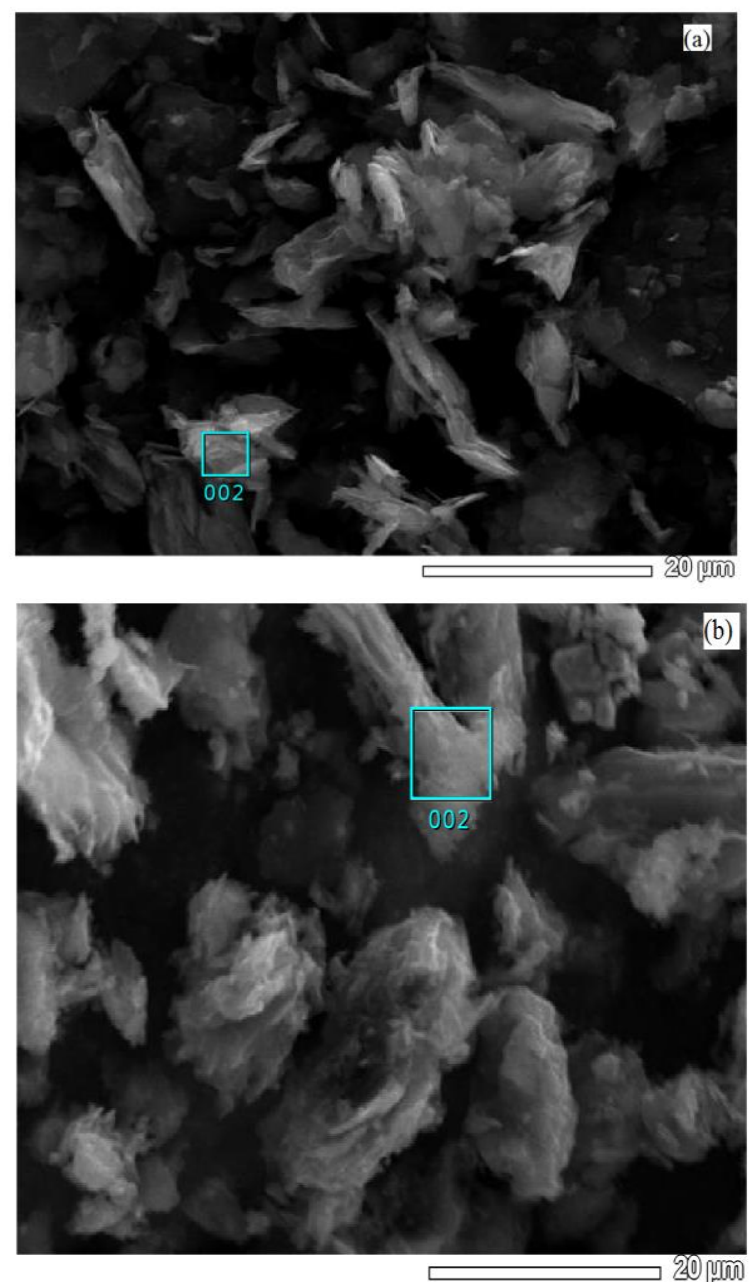

Figure 4. SEM images of (a) Commercial Graphite (b) Local Graphite.

BET surface area and porosity are closely related to the corrosion properties of graphite. The greater the sur-face area, the resistance to corrosion decreases. High porosity will affect electrical resistance, heat conductivity, elastic modulus, material permeability and transport properties of fission products [19].

Pore size distribution is calculated using Density Functional Theory (DFT) method as can be seen in Figure 6. Local and commercial graphite has a similar pore structure. There are at least 3 pore size quantities observed in Figure 6, namely; pore sizes of $4 \mathrm{~nm}$ (most dominant), $7.5 \mathrm{~nm}$ and $14 \mathrm{~nm}$. Clearly, the size of this pore diameter is in the range of $2 \mathrm{~nm}-50 \mathrm{~nm}$, meaning that both graphites have a mesopore system.

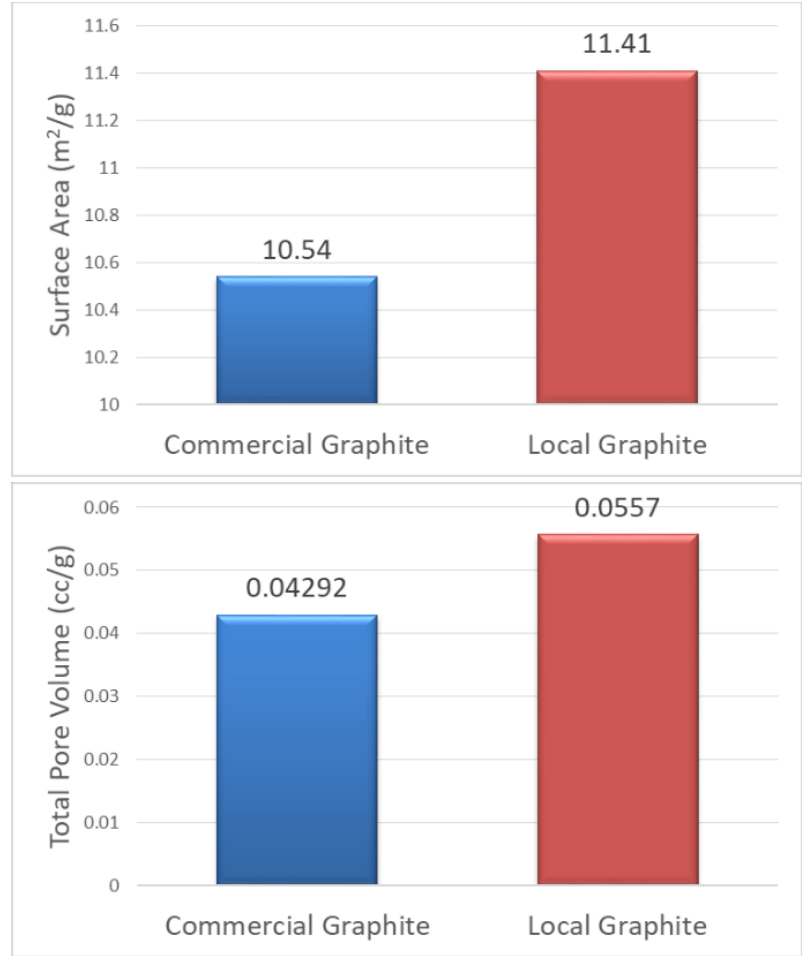

Figure 5. Surface area and total pore volume of commercial and local graphites.

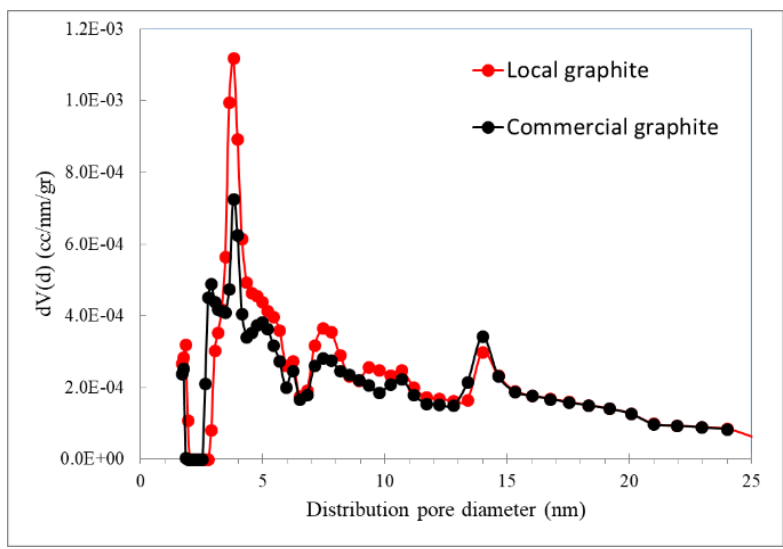

Figure 6. Pore size distribution with DFT method of Commercial Graphite and Local Graphite

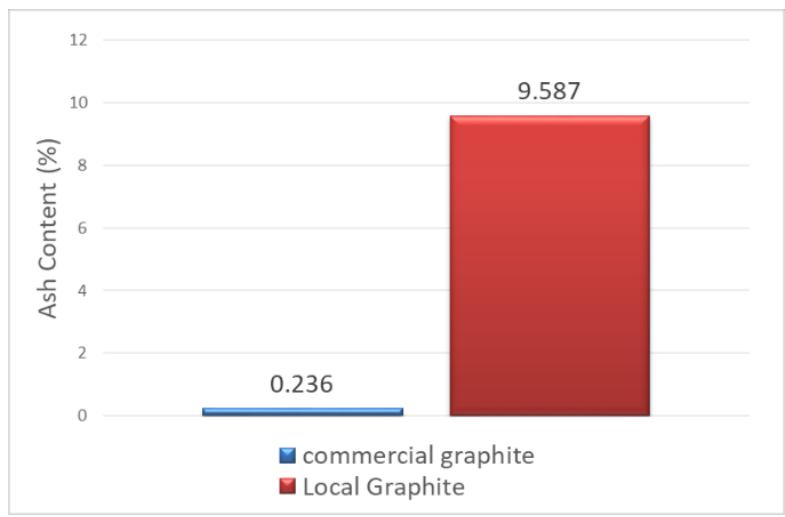

Figure 7. Ash contents of commercial and local graphites 
The results of the ash content measurement of commercial graphite and local graphite are shown in Figure 7. Ash content of local graphite (9.587 \pm $0.010 \%$ ) is greater than the ash content of commercial graphite $(0.236 \pm 0.029 \%)$. Sunghwan Yeo et.al. mention nuclear graphite ash content $<100$ ppm [4]. The results show that the impurity content in commercial graphite and local graphite is still quite high.

\section{CONCLUSION}

Indonesian graphite has the potential to be refined into nuclear graphite to meet the construction needs of Experimental Power Reactor. However, the results of various characterizations show that natural graphite which has been treated by flotation still does not meet the criteria for nuclear graphite, especially in its impurity content. The carbon content of graphite from flotation is $87.0 \%$, meaning that there are still around $13 \%$ of materials other than carbon in graphite. These data area supported by the results of determining the content of metals in graphite which is still quite high. Continuing this research, graphite from the flotation still requires further processing, especially in terms of refinement. This can be conducted by chemical or thermal means to eliminate impurity so that it meets the criteria as nuclear graphite to meet the material needs of RDE fuel matrix.

\section{ACKNOWLEDGEMENT}

The author would like to thank Kemenristekdikti (Ministry of Research, Technology and Higher Education) for funding this research in the Flagship Insinas program, Dr. Geni Rina Sunaryo, M.Sc, Ir. Agus Sumaryanto, M.S.M and Prof. Ridwan, who have facilitated the conduct of this research. Colleagues at UNPAD, PSTBM and PTBBN have helped a lot in conducting this research.

\section{REFERENCES}

[1]. T. Setiadipura, S. Bakhri, G. R. Sunaryo, and D. S. Wisnusubroto, "Cooling passive safety features of Reaktor Daya Eksperimental," AIP Conf. Proc., vol. 1984, 2018.

[2]. C. Tang, Y. Tang, J. Zhu, Y. Zou, J. Li, and X. $\mathrm{Ni}$, "Design and manufacture of the fuel element for the $10 \mathrm{MW}$ high temperature gas-cooled reactor," Nucl. Eng. Des., vol. 218, no. 1-3, pp. 91-102, 2002.

[3]. H. Zhao, T. Liang, J. Zhang, J. He, Y. Zou, and C. Tang, "Manufacture and characteristics of spherical fuel elements for the HTR-10," Nucl. Eng. Des., vol. 236, no. 5-6, pp. 643-647, 2006.

[4]. S. Yeo, J. Yun, S. Kim, M. S. Cho, and Y. W. Lee, "Fabrication methods and anisotropic properties of graphite matrix compacts for use in HTGR," J. Nucl. Mater., vol. 499, pp. 383-393, 2018.

[5]. IAEA, "High Temperature Gas Cooled Reactor Fuels and Materials," IAEA Tecdoc 1645, pp. 1-
182, 2010.

[6]. P. P. Magampa, N. Manyala, and W. W. Focke, "Properties of graphite composites based on natural and synthetic graphite powders and a phenolic novolac binder," J. Nucl. Mater., vol. 436, no. 1-3, pp. 76-83, 2013.

[7]. X. Zhou et al., "Study on the Comprehensive Properties and Microstructures of A3-3 Matrix Graphite Related to the High Temperature Purification Treatment," Hindawi Sci. Technol. Nucl. Install., 2018.

[8]. X. W. Zhou, Y. P. Tang, Z. M. Lu, J. Zhang, and B. Liu, "Nuclear graphite for high temperature gas-cooled reactors," Xinxing Tan Cailiao/New Carbon Mater., vol. 32, no. 3, pp. 193-204, 2017.

[9]. T. Indrayati and Sudaryadi, "Penyiapan umpan grafitisasi dengan metoda granulasi bertahap," Pros. PPI - PDIPTN, pp. 278-282, 2007.

[10]. F. F. Florena et al., "Floatability study of graphite ore from southeast Sulawesi (Indonesia)," AIP Conf. Proc., vol. 1712, 2016.

[11]. I. M. Joni et al., "Synthesis and dispersion of nanoparticles, and Indonesian graphite processing," AIP Conf. Proc., vol. 1554, pp. 2026, 2013.

[12]. C. Panatarani, A. O. Maulana, A. Rianto, and I. M. Joni, "Preparation of graphite oxide by sodium cholate intercalation and sonication from Indonesian natural graphite," AIP Conf. Proc., vol. 1712, no. March 2016, 2016.

[13]. R. Marza, W. Setiyawan, and H. Rodiana, "Keprospekan Mineral Grafit di Pulau Kalimantan dan Pulau sulawesi," Pros. Has. Kegiat. Pus. Sumber Daya Miner. Batubara dan Panas Bumi Tahun Anggar. 2017, vol. Buku 2 : B, pp. 219-229, 2018.

[14]. B. J. Marsden, G. N. Hall, 2012, "Graphite in gas - cooled reactors", Comprehensive Nuclear Materials Volume 4, Elsevier, Amsterdam, pp 325-390

[15]. H.G. Maahs, D.R. Shryer, "Chemical impurity data on selected artificial graphites with comments on the catalytic effect of impurities on oxidation rate", NASA Technical Note (NASA TN D-4212, National Aeronautic and Space Administration, Washington, D.C. 1967.

[16]. X. Luo, X. Wang, L. Shi, X. Yu, and S. Yu, "Nuclear graphite wear properties and estimation of graphite dust production in HTR-10," Nucl. Eng. Des., vol. 315, pp. 35-41, 2017.

[17]. W. Windes, G. Strydom, R. Smith, J. Kane, 2014, "Role of nuclear grade graphite in controlling oxidation in modular HTGRs ", IN/EXT-1431720, Idaho National Laboratory, U.S. Department of Energy National Laboratory. 2014.

[18]. ASTM, "Standard Practice for Determining Equivalent Boron Contents of Nuclear materials C 1233". ASTM International. 1993 
[19]. IAEA, “Advances in High Temperature Gas

TECDOC CD 1674, 2012, pp. 1-690. Cooled Reactor Fuel Technology," in IAEA 4.0 International License (CC BY-NC-SA 4.0). 